بررسى نشست بدنه سد خاكى در دوران ساخت و مقايسه آن با نتايج تحليلى با استفاده از نرمافزار PLAXIS (مطالعه موردى سد كبودوال)

فرزين سلماسى، حسين حكيمى خانسر " و بهرام نورانى'

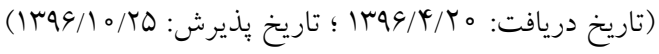

جكيده

در مدلسازى سد كبودوال با استفاده از نرمافزار پِاكسيس، از مدل رفتارى موهر - كلمب استفاده شـده اسـت و تـأثير دو عامـل اسـتمرار

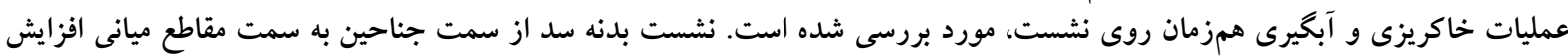

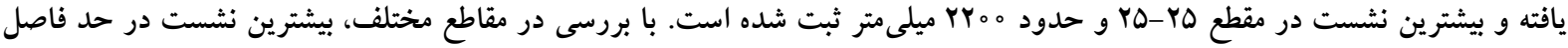

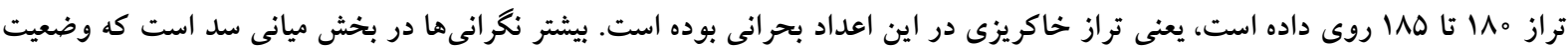

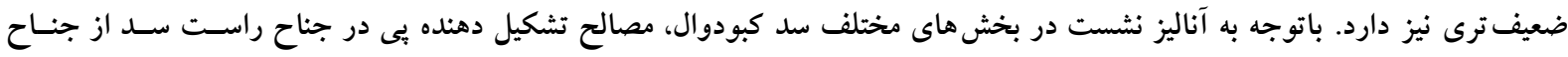

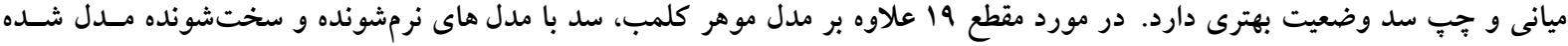

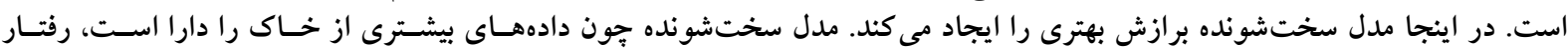

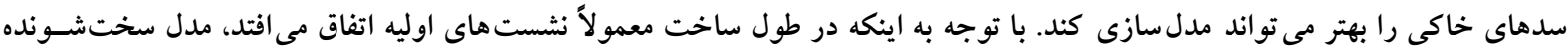
كارايى بهترى مى تواند داشته باشد.

وازههاى كليدى: سد خاكى، سد كبودوال، يلاكسيس، نشست

1. كروه مهندسى آب، دانشكده كشاورزى، دانشگاه تبريز * مسئول مكاتبات: بست الكترونيكى: hakimi1904@yahoo.com 
كه در نتيجه افز ايش تدريجى ارتفاع سد ممكن است رخ دهـــ نيـز

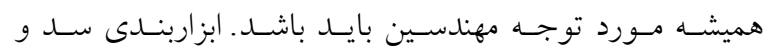

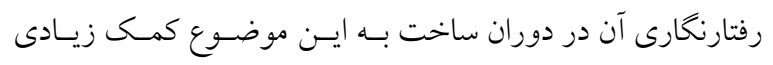

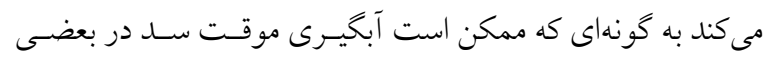
مراحل ساخت ييشنهاد شود (19). در تحقيق حاضر سعى شده است دادههاى ابزار دقيق در دوران

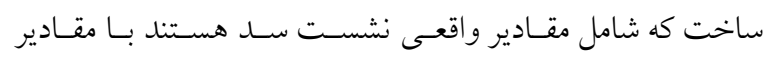

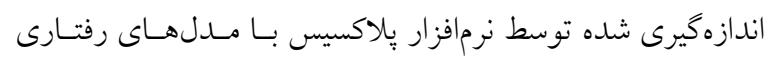

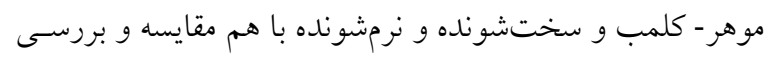

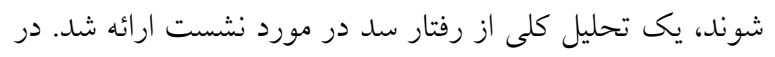
انتها بهترين مدل رفتارى براى شبيهسازى سدهاى خاكى ييشـنهاد

\section{مواد و روشها - ماد} معرفى سد سد كبودوال واقع در شهر على آباد در استان كلسـتان اسـت. ايسن

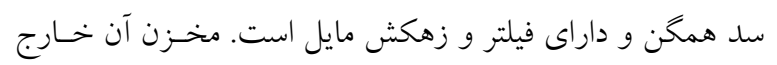

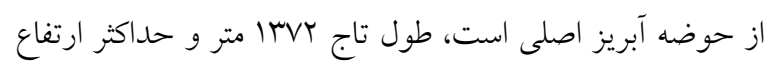

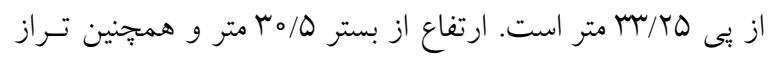

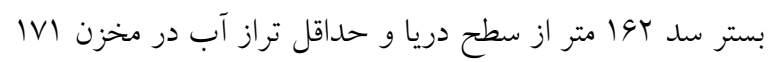

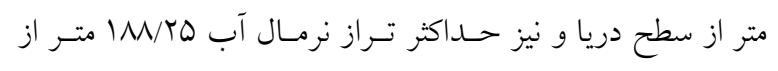

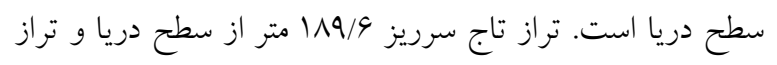

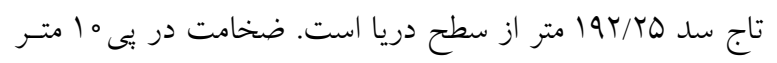
و آب قابل تنظيم ساليانه حدود هه ميليون متر مكعب است (Y) (Y).

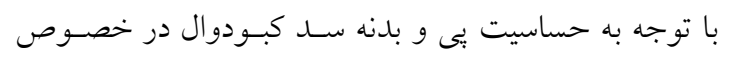

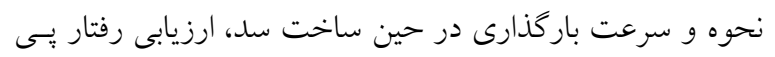

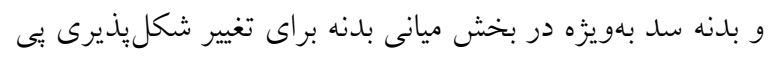

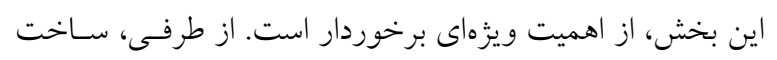

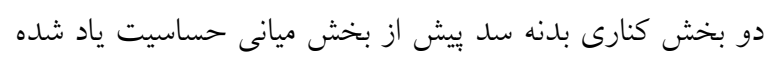

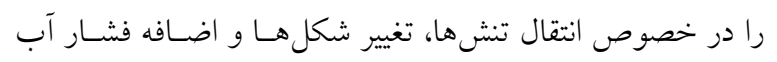

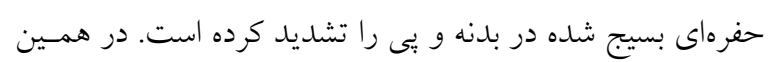

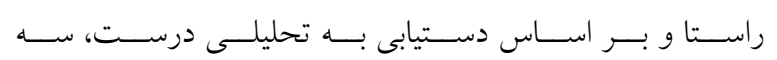

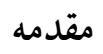
وقتى سد خاكى يا خاكريزهاى ساخته شود، تسنش خـاك موجـب

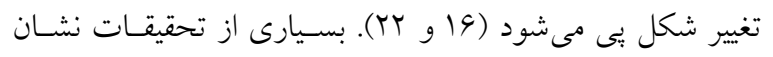

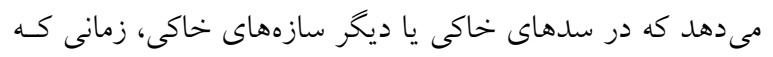

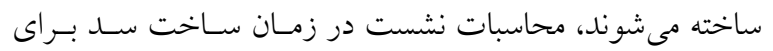

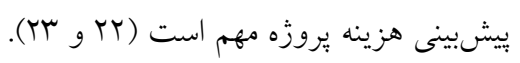

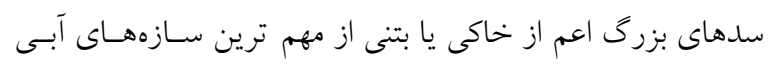

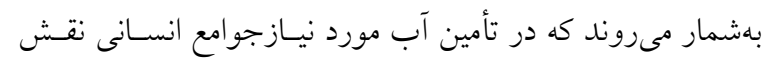

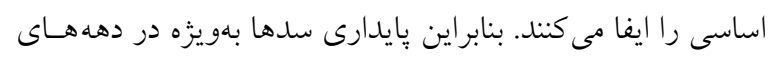

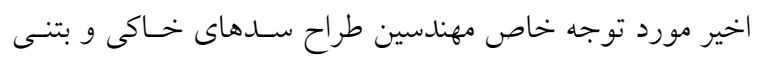
بوده است (11). اهميت ويزه ابزار دقيق در سدها به نقش آنها در بردي كترل بايدارى كوتاه و درازمدت سدها برمى گردد، به گونه اى كـه

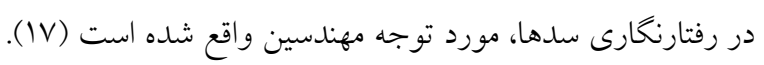

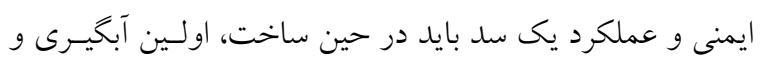
در دوران بهره بردارى كنترل شـود. اولـين دوره آبخيــى احتى احتمالاً

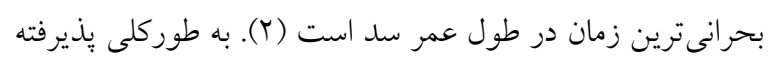

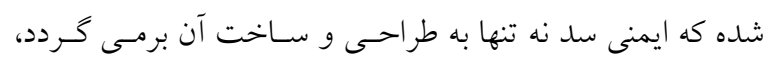

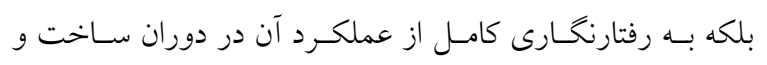

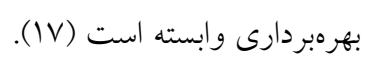

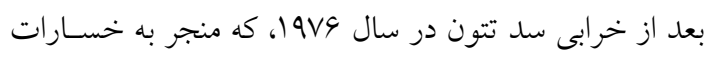

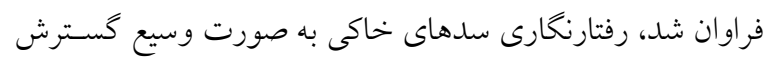

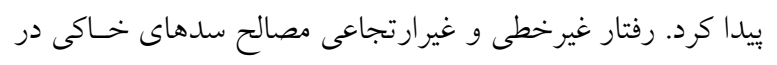

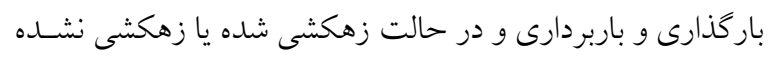

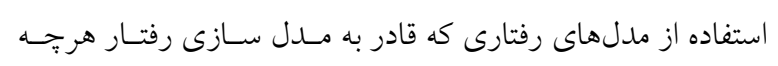

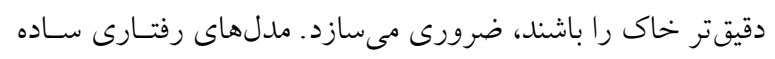

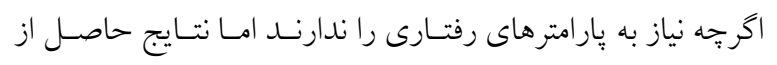

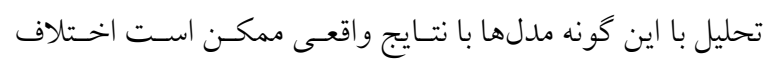

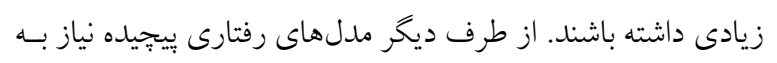

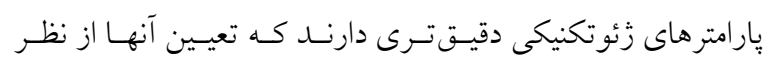

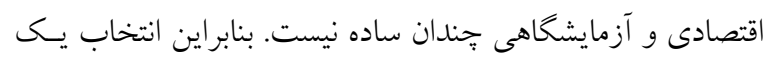

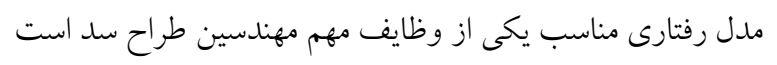

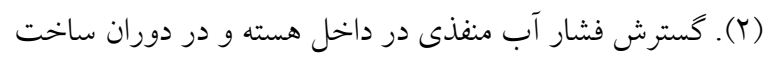



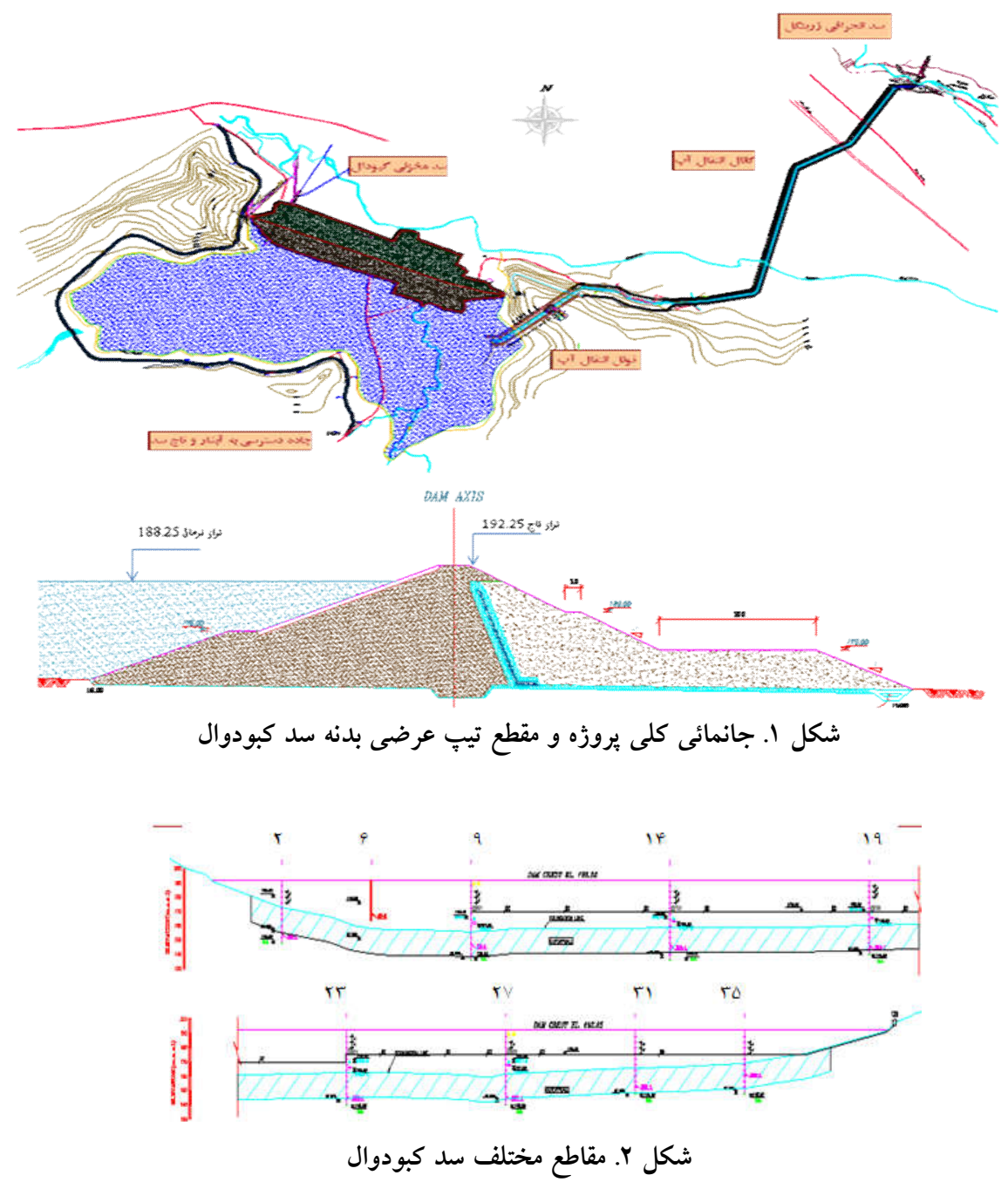

ابزار دقيق كه شرح داده شد، تطبيق داده و نــرمافـزار بــــاى مــدل

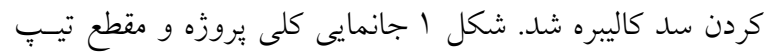

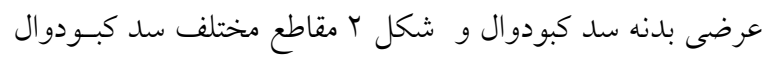
را نشان مىدهد.

$$
\text { مدلسازى عددى }
$$

انواع مدل هاى رفتارى خاك در بِاكسيس لمديس

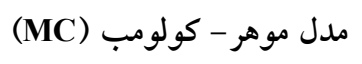

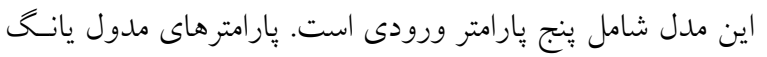

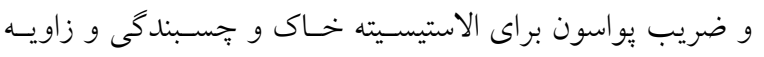

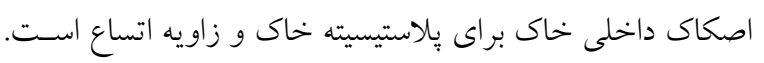

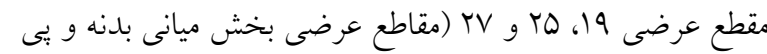

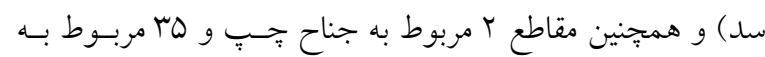

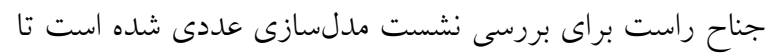

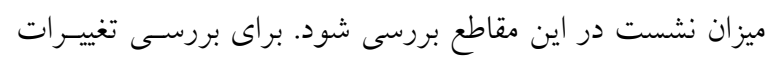

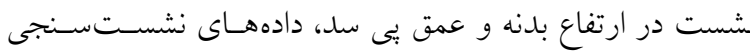

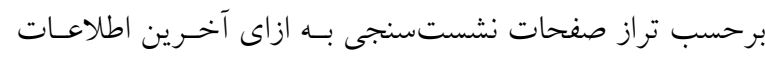
تجمعى منتهى به دوران قريب به پايان ساخت در شكلهـائى بــهـ تفكيك انحرافسنجهاى نصب شده در هر مقطع ارائه شده است.

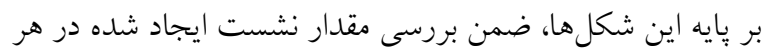

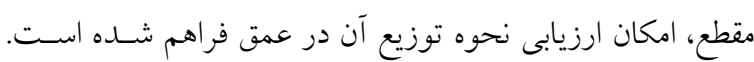
درنهايت با يك تحليلى برگشتى، نتايج حاصل از نرمافزار با نتايج 


$$
\begin{array}{r}
g(\mathrm{j}, \mathrm{i}, \mathrm{k})=\frac{1}{r}\left|\left[\sigma_{(\mathrm{j}, \mathrm{k}, \mathrm{i})}^{\prime}-\sigma_{(\mathrm{k}, \mathrm{i}, \mathrm{j})}^{\prime}\right]\right|+\frac{1}{r} \\
\left|\left[\sigma_{(\mathrm{j}, \mathrm{k}, \mathrm{i})}^{\prime}+\sigma_{(\mathrm{kij})}^{\prime}\right]\right| \sin \varnothing \leq 。
\end{array}
$$$$
\text { بهصورت رابطه كلى زير مىتوان تعريف كرد: }
$$

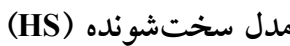

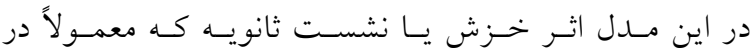
درازمدت اتفاق مى افتد درنظر كرفته نمىشود. بديهى است بـا بـا

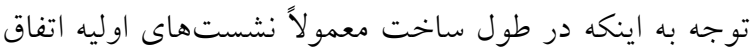
مى افتد مدل سختشونده كارايى بهترى مى تواند داشته باشـــ.

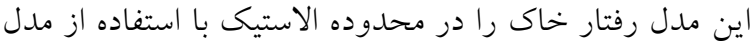
هايبربوليك، شبيه سازى مى كند. اين مدل شامل سخت شـونده

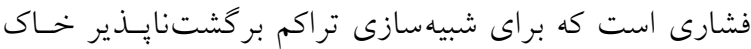

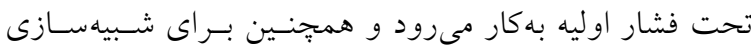
رفتار ماسه و شن و هم براى انواع نرمتر خاك همانند سيلتها

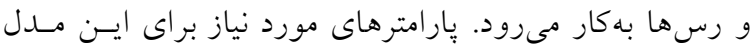

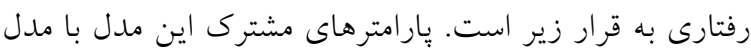

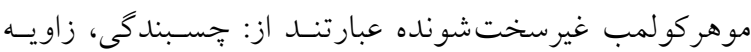

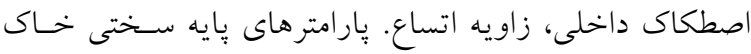
عبارتند از: سختى سكانتى در آزمايش سه محسورى استاندارد

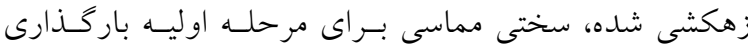

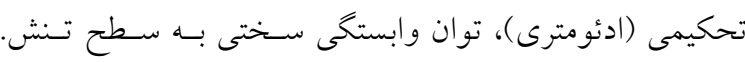

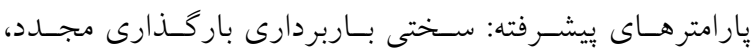

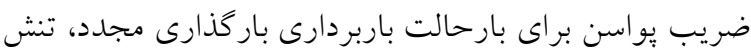

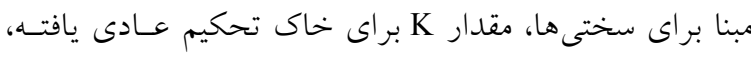

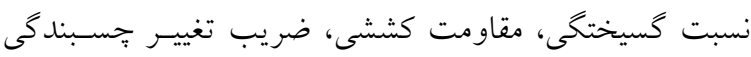
مانند مدل موهر كولمب (Y). در مــل رفتـارى سـختشـونده

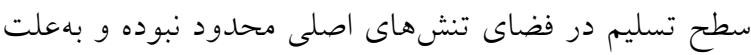

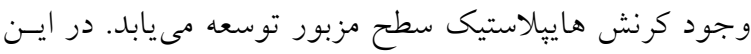

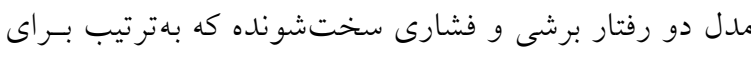

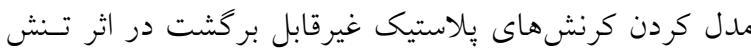
انحرافى و تنش فشارى همه جانبه بهكار مىروند، وجود دارد.

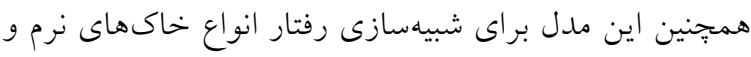

مدل موهر كلمب يك تقريب مرتبه اول از رفتار سنگ يا خـاك را

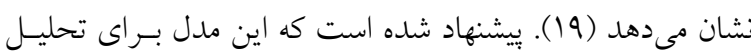
اوليه از مسئله استفاده شود. مدل مـوهر - كولمـب از سـادهتـرين

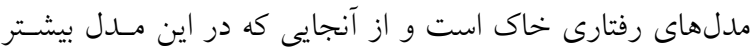

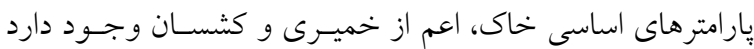

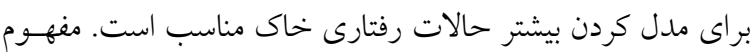

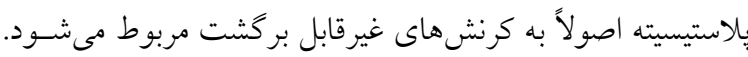

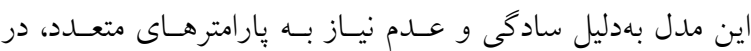

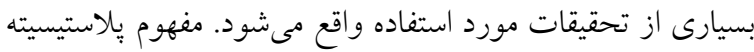

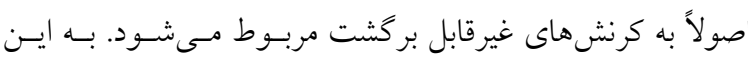

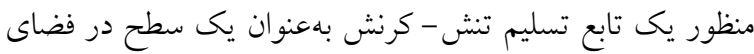

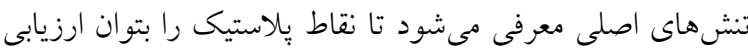

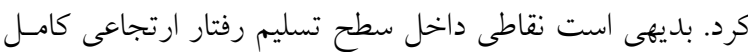

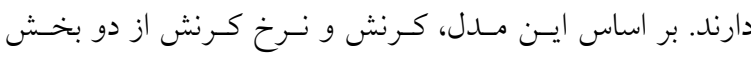

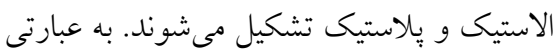
$\underline{\sigma}^{\prime}=\left(\underline{\underline{D}}^{\mathrm{e}}-\frac{\mathrm{a}}{\mathrm{d}} \underline{\underline{D}}^{\mathrm{e}} \frac{\partial \mathrm{g}}{\partial \sigma^{\prime}} \frac{\partial \mathrm{f}^{\mathrm{t}}}{\partial \sigma^{\prime}} \underline{\underline{\mathrm{D}}}^{\mathrm{e}}\right) \varepsilon^{0^{\prime}}$

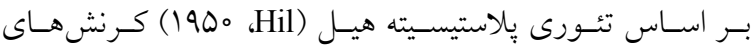
دِلاستيك متناسب با مشتق تابع تسليم نسبت به تنشها است. بـهـ

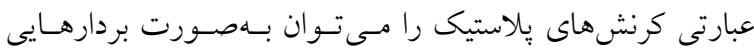

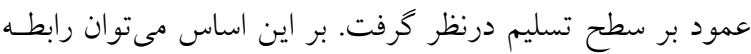
بين نرخ تنش مؤثر و كرنش مؤثر را بهدست آورد. $\mathrm{d}=\frac{\partial \mathrm{g}}{\partial \sigma^{\prime}} \underline{\underline{D}}^{\mathrm{e}} \frac{\partial \mathrm{f}^{\mathrm{t}}}{\partial \sigma^{\prime}}$

در اين رابطه است. معيار تسليم مور - كلمب از شش تابع تسـليم

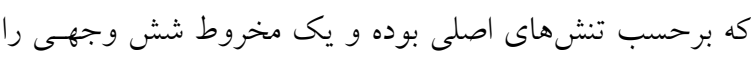

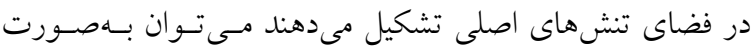

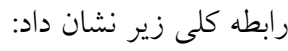

$f($ j. i. k $)=\frac{1}{r}\left|\left[\sigma_{(\text {j.k. i) }}^{\prime}-\sigma_{(\text {k. i. j) }}^{\prime}\right]\right|+\frac{1}{r}$

$\left|\left[\sigma_{(j . k . ~ i)}^{\prime}+\sigma_{(k . ~ i . j)}^{\prime}\right]\right| \sin \varnothing-c \cos \varnothing \leq 。$

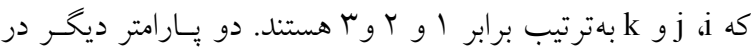

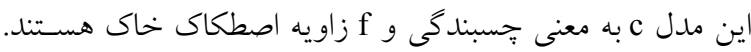

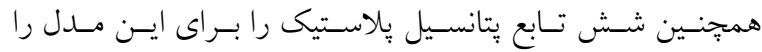


مدل خاك سختشونده تابع تنش بودن مـدول سـختى را لحـاظ كرده است. يعنى تمام سختىها با فشار افزايش مى يابند. بنـابراين

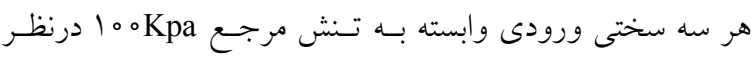

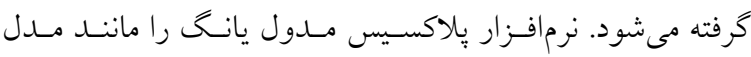
سختى بايه در مدل الاستيك و مدل موهر كلمب استفاده مسى كنــد.

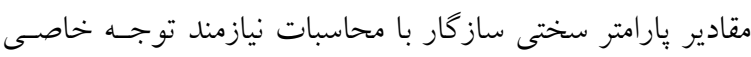

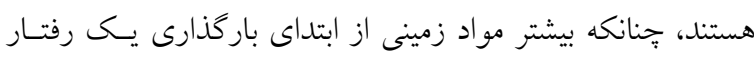

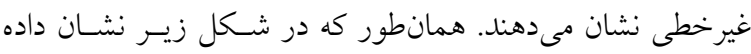

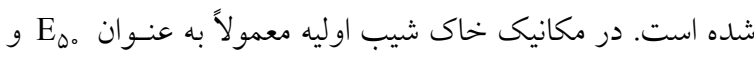

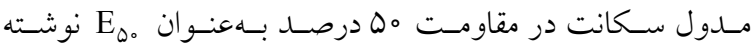

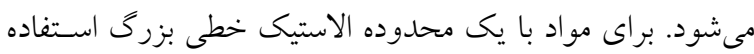

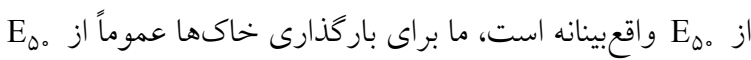

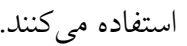

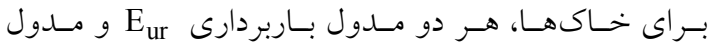

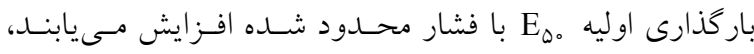

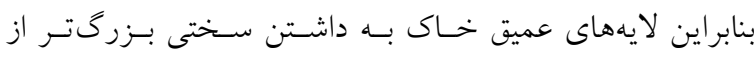
لايههاى كمعمقتر منجر مىشوند. علاوه بر اين، سختى مشاهده

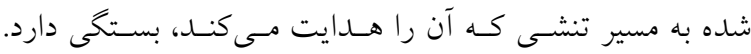

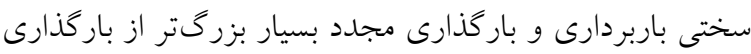

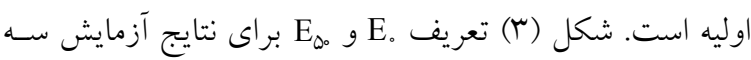
محورى زهكشى شده را نشان مىدهد.

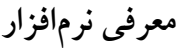
نرم|فزار پِلاكسيس براى تحليل تغييرشكل و پِايدارى در بروزمهاى

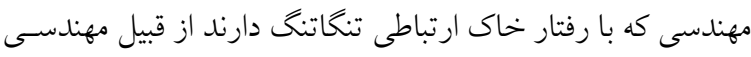

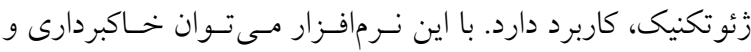

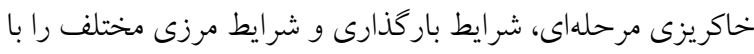

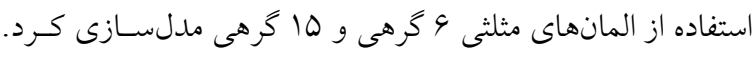

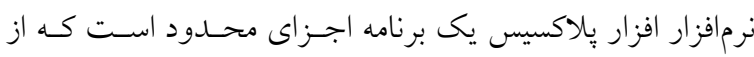

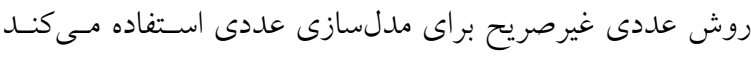

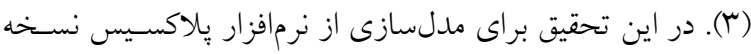

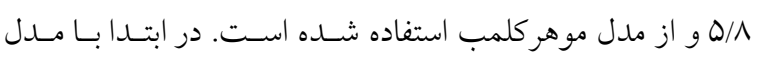

سخت كاربرد دارد. هنگكامى كه خاك تحت تنش انحر افى قرار

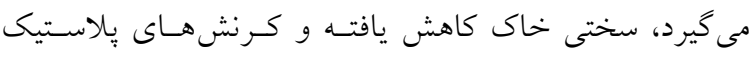

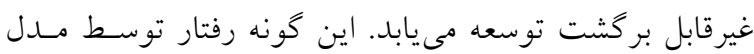

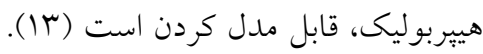

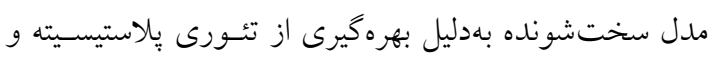

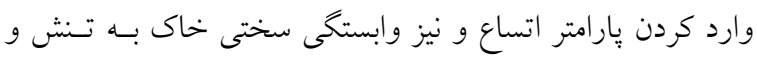
كرنش، جايكزين مناسبترى است. يكى از ويزَّى هاى اين مــدل

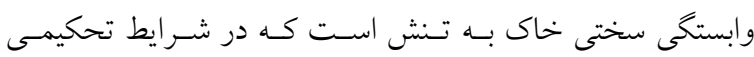
بهورت زير قابل بيان است: براى خاكهاى نرم فرض أس به به واقعيت نزديك است. در ايسن

$\mathrm{E}_{\mathrm{oed}}=\mathrm{p}^{\mathrm{ref}} / \lambda^{*}$

در اين روابط تنش مرجع و انديس فشردگى اصلاح شده اسـت.

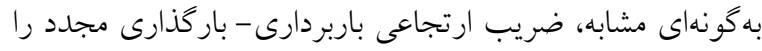

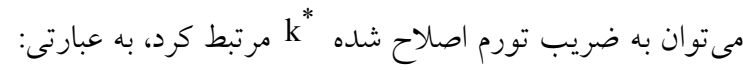
$E_{\text {ur }}^{\text {ref }}=r p^{r e f}\left(1-r v_{u r}\right) / k^{*}$

$\mathrm{k}^{*}=\mathrm{k} /\left(1+\mathrm{e}_{\mathrm{o}}\right)$

كه Vu vر اين مدل اثر خزش يا نشست ثانويه كه معمولاً در

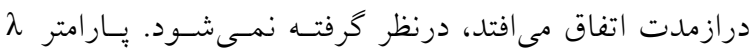

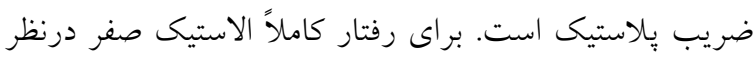

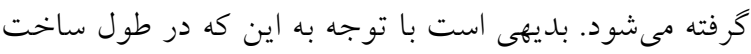

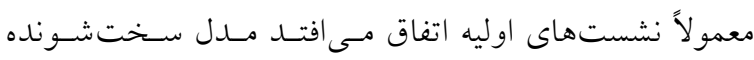
كارايى بهترى مى تواند داشته باشد. اين مدل يكى مدل ييشرفته

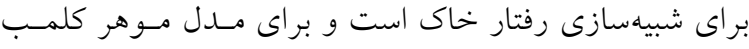
حالات محدود تنش بهوسيله زاويه اصطكاك و جسبندكى c و زاويه اتساع 4 توصيف مىشود. اكرجهه سختى خاك با استفاده از سه ورودى متفاوت سختى بسيار دقيق تر توصيف مىشـود.

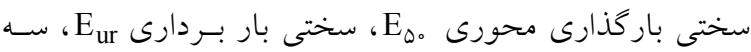

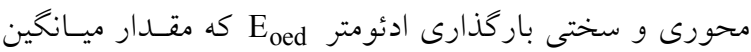
براى انواع مختلف خاك داريم:

$E_{\text {oed }}=E_{\diamond, \rho} E_{u r}=r E_{\diamond}$

فرق اساسى مدل موهر كلمب و خاك سختشونده اين است كـهـ 


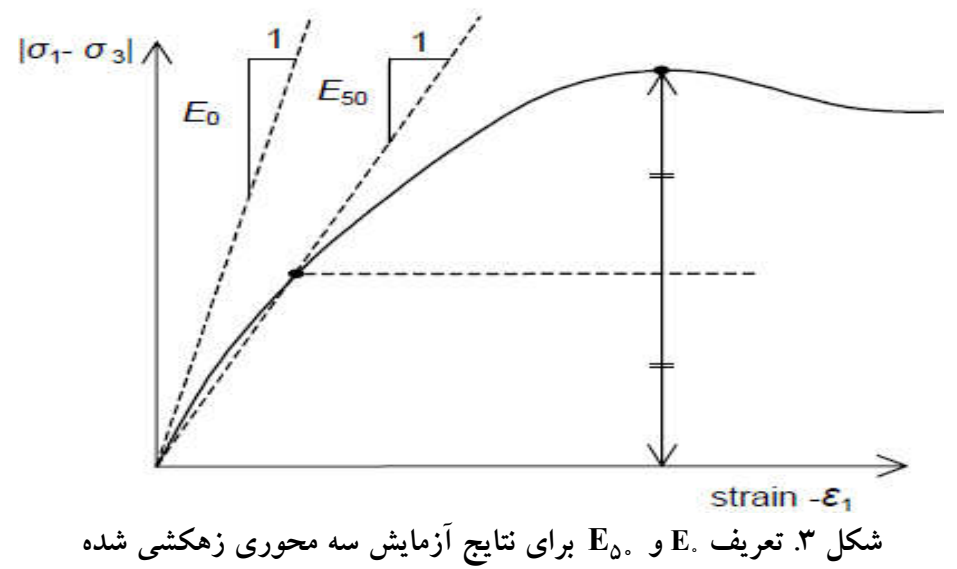

جدول ا. مشخصات مصالح در مدل رفتارى سختشونده، موهر كلمب و نرمشونده

\begin{tabular}{|c|c|c|c|c|c|c|c|c|}
\hline $\begin{array}{c}K_{x, y} \\
(\mathrm{~m} / \mathrm{day})\end{array}$ & $\begin{array}{l}\Phi \\
\left({ }^{\circ}\right)\end{array}$ & $\begin{array}{c}C_{r e f} \\
\left(\mathrm{kN} / \mathrm{m}^{2}\right)\end{array}$ & $v$ & $\begin{array}{c}E_{r e f} \\
\left(\mathrm{kN} / \mathrm{m}^{2}\right)\end{array}$ & $\begin{array}{c}\gamma_{\text {sat }} \\
\left(\mathrm{kN} / \mathrm{m}^{3}\right)\end{array}$ & $\begin{array}{c}\gamma_{\text {unsat }} \\
\left(\mathrm{kNN} / \mathrm{m}^{3}\right)\end{array}$ & نوع مصالح & خصو صيات مصالح \\
\hline$r e-\Lambda / 9 \Lambda$ & rq & 11 & $\circ / r$ & $\mathrm{re}+\mathrm{l} / 0$ & ro & IV & Undrain & بיى \\
\hline$r e-\Lambda / 9 \Lambda$ & TQ & rr & $0 / 4$ & $\mathrm{re}+\mathrm{l} / 。$ & rr & 19 & Drained & بدنه \\
\hline$N / 94$ & re & ir & $0 / r \Delta$ & rQo. & rI & ro & Drained & فيلتر و زهكش \\
\hline
\end{tabular}

جدول Y. مشخصات تكميلى مصالح در مدل رفتارى سختشونده و نرمشونده

\begin{tabular}{|c|c|c|c|c|}
\hline $\mathrm{K}_{\mathrm{o}}^{\mathrm{nc}}$ & $\begin{array}{c}\mathrm{E}_{\mathrm{ur}} \\
\left(\mathrm{KN} / \mathrm{m}^{r}\right)\end{array}$ & $\begin{array}{c}\mathrm{E}_{\mathrm{oed}} \\
\left(\mathrm{KN} / \mathrm{m}^{r}\right)\end{array}$ & $\begin{array}{c}\mathrm{E}_{\Delta_{\circ}} \\
\left(\mathrm{KN} / \mathrm{m}^{r}\right)\end{array}$ & خصو صيات مصالح \\
\hline$\circ / 4 \vee \wedge$ & $\mathrm{re}+\mathrm{Q}$ & $r_{e}+r / D$ & $Y \mathrm{e}+\mathrm{r} / \mathrm{Q}$ & بدنه \\
\hline
\end{tabular}

بِلاكسيس كه به روش آنـاليز برگشتى بـهدسـت آمــه، را نشـان مى دهن. در جداول فوق c جسبندگى (مؤثر)، $\Phi$ زاويه اصكاك داخلى

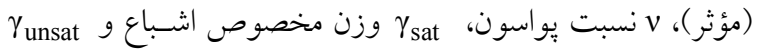

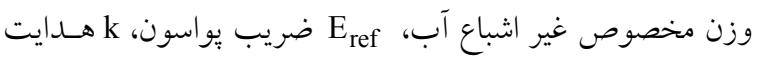

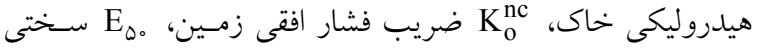

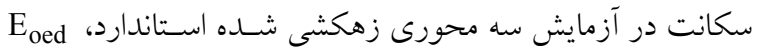

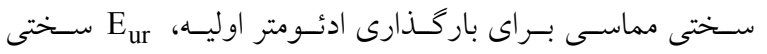
باربردارى و بار كذارى مجدد هستند.

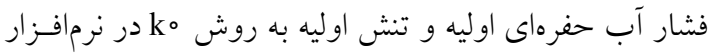

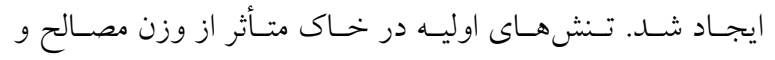

كردن هندسه بستر و لحاظ كردن شـر ايط مــرزى مــدل، بـهمنظـور

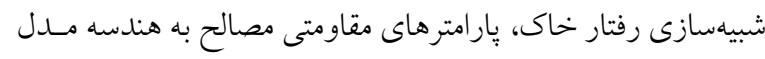

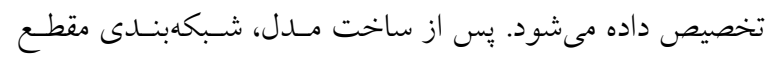

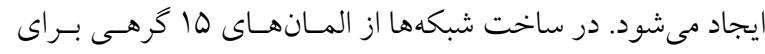

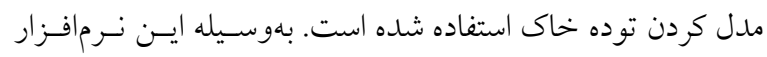

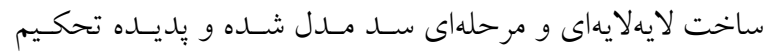

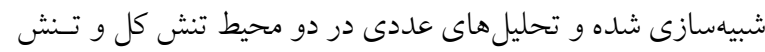

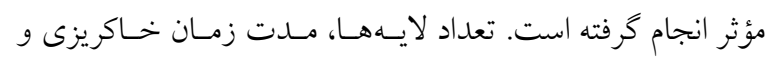
مقدار زمان تحكيم بر اساس برنامه زمانبندى اجراى سد بـ بود كـهـ

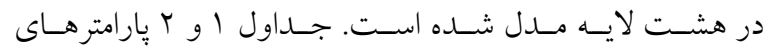
زُئوتكنيكى مصالح، مدل موهر كلمب استفاده شـــه در نـرم|فـزار 


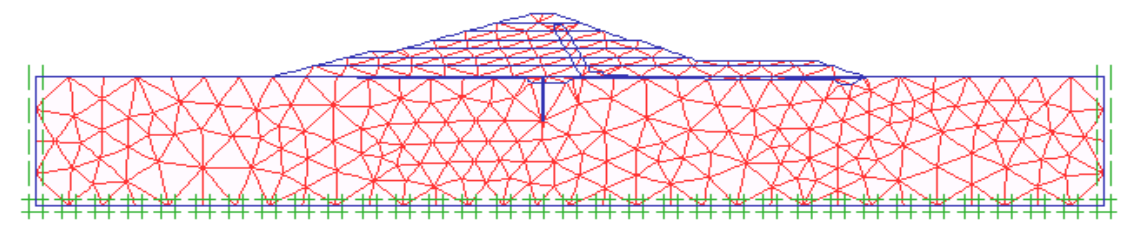

شكل f. هندسه مدل و شبكهبندى مقطع 19
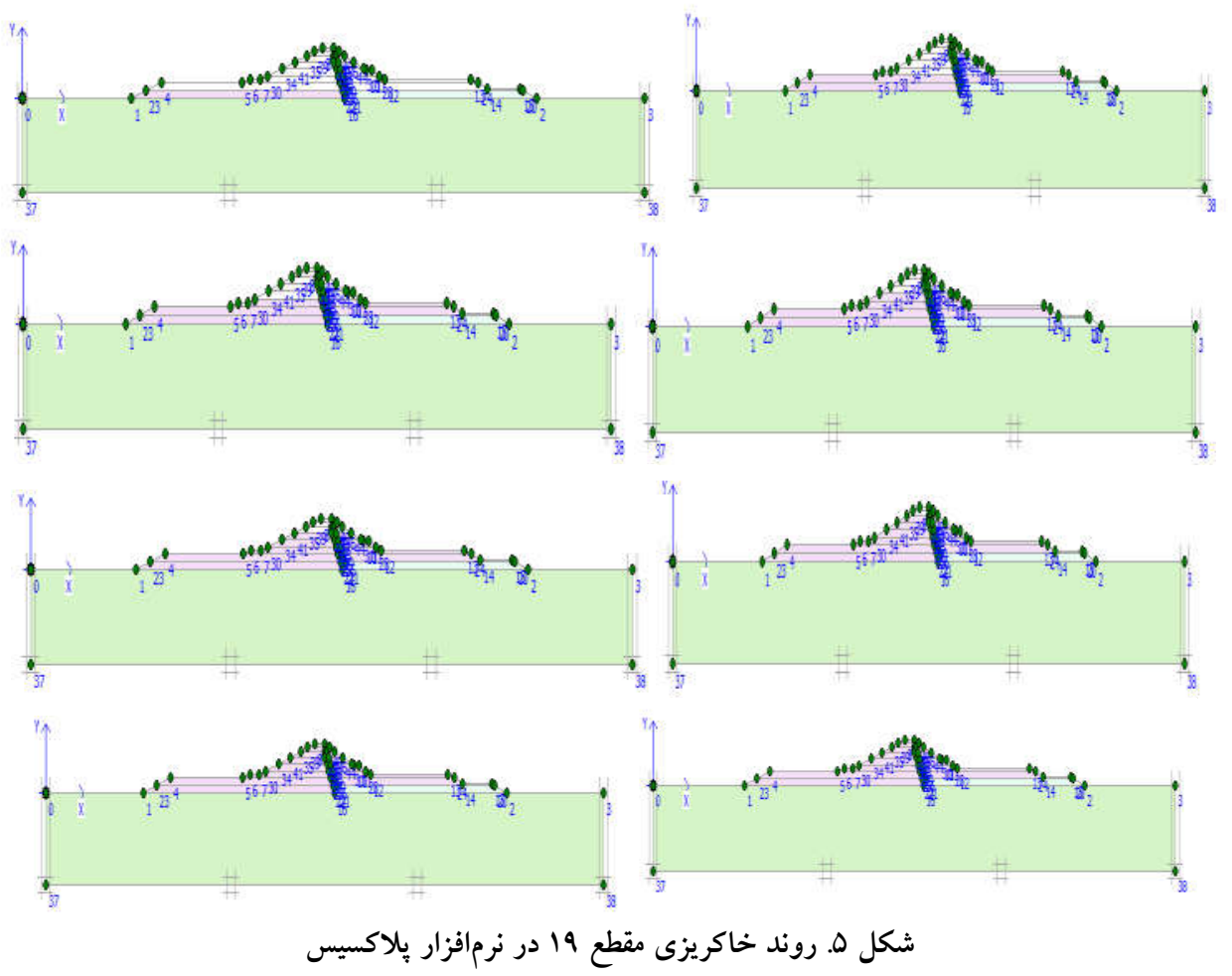

در مورد شبكهبندى نرم|فزار اين نكته قابل ذكر است كه سه نـوع

شبكه ريز، متوسط و درشت قابل استفاده است كه عمل شبكهبندى با توجه به دقت و يكى از روشهاى فوق خودكار انجـام مسىشـود. در شكل (Y) عمق ديواره آب بند مطابق نقشههاى اجرايى ســ برابـر 19 متر درنظر كرفته شد. هدايت هيدروليكى بخـش هـاى مختلـف ســـ مانند بدنه، بى و فيلتر در جدول ا ارائه شده است.

تعيين تعداد لايههاى لازم براى مدلسازى ساخت مرحلهاى و اقعيت اين است كه در مدلسازى سدهاى خـاكى يـك حـداقل تعداد لايه براى رسيدن به جوابهاى قابل قبول در مـورد تغييـر شكلها وجود دارد، بنابراين مشخص كردن تعداد لايسههــا مـورد
تاريخجه تشكيل آنها است كه معمولاً بهصورت تنش مـؤثر اوليسه عمودى مشخص مىشود. تنش مؤثر اوليه عمودى ضرب در k0 مساوى تنش مؤثر اوليه افقى است. تنش اوليه بهوسـيله مشخصـه يا با استفاده از بار كذارى ثقلى ايجـاد مسى شـود. در ادامـه در نرمافزار 19 يا ها فاز محاسباتى (بسته به نوع مقطع و با توجه به برنامه زمانبندى اجرا) براى خاكبردارى و خاكريزى مقاطع ســـ به روش ساخت مرحلهاى تعريف شد و درنهايت بـا يـك آنـاليز بركشتى نتايج با دادههاى ابزار دقيق تقريباً يكى شد و بـهـ تحليـل آنها يرداخته شده است. شكل (Y)، هندسـه مـدل و شـبكهبنـدى مقطـع 19 و شـكل ه، رونـــ خــاكيزى مقطـع 19 در نـرمافـزار يلاكسيس را نشان مى دهد. 


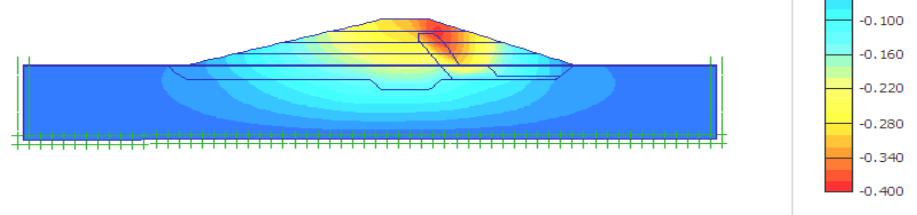

Vertical displacements (Uy) Extreme Uy $-385.21^{*} 10^{-3} \mathrm{~m}$

شكل 9. نشست در آخرين مرحله خاكريزى مقطع r

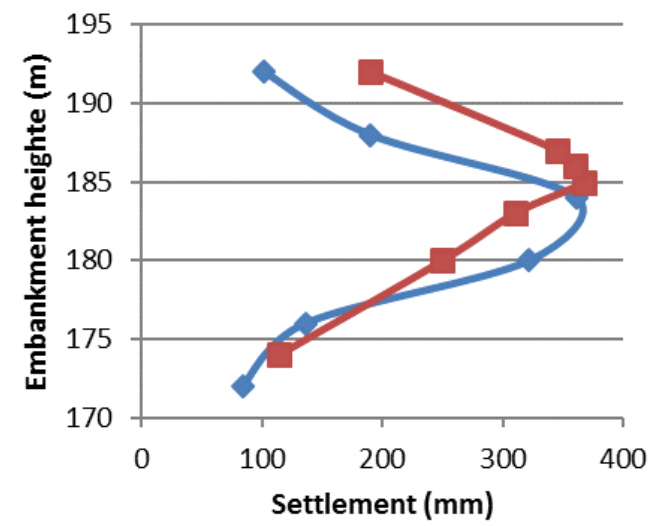

-Measured by Dam

Instruments section 2

Calculated plaxis 2d

(Mohr Coulomb model)

شكل V. وضعيت تغييرات نشست با ارتفاع خاكريزى مقطع r حاصل از ابزار دقيق و آناليز برگثتى

خاكريزى مقطع r حاصل از ابزار دقيق و آناليز بركشـى را نشـان

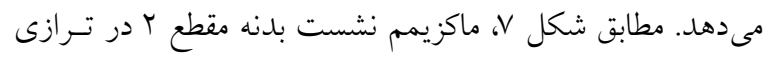

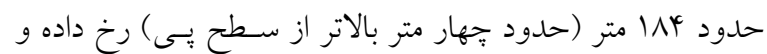
مقدار آن معادل هوس ميلىمتر تا بيش از تكميل خاكريزى كمربند فوقانى سد بوده است. در ترازهاى بالاتر بدنه سد مقدار نشسـت كاهش يافته است. نشست تجمعى بيى در اين مقطع بـراى دوران

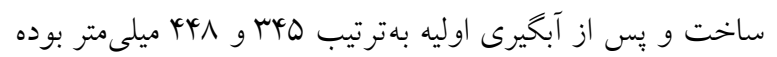
و 9/0 متر عمق سطحى يى نشست بيشترى را تجربه كرده است.

بررسى نشست مقطع 19 مقطع ميانى سد و مقايسه مدل عددى با نتايج ابزار دقيق مقطع شماره 19 در كيلومتراز ه9 9+ه واقع شده، مىتواند بهعنوان اولين مقطع بخش ميانى بدنه سد بررسى شود. بيشـترين نشستـ تجمعى بلنه و يى اين مقطع در دوران ساخت سد م1/D ميلىمتر بوده است. نشست بدنه سد در اين مقطع تناظر مناسبى با مقـاطع
نياز در تحليل اهميت دارد. زمرديان و جوجيى اثـر تعـداد لايسههـاى شبيهسازى شده مدلهاى كامييوترى روى يارامترهايى تحليلى كتترل كننده در سدهاى خاكى با هسته رسى قائم مسجد سليمان را بررسى

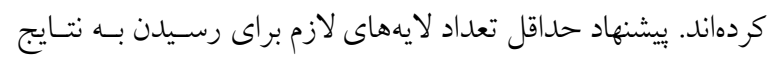
معقول در مدلهاى كامييوترى H/10 ارايه كردهانـد و كـه H ارتفـاع سد از يى است (V). در اين مقاله اين قانون رعايت شده است. روند خاكريزى طبق برنامه زمانبندى اجرا ســ شـبيهسـازى

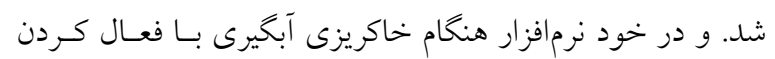
تراز سطح آب در ارتفاع خواسته شده ايجاد شد.

نتايج و بحث بررسى نشست مقطع Y جناح جֶٍ سد و مقايسه مـدل عـددى با نتايج ابزار دقيق شـكل و نشست در آخــرين مرحلـه خـاكريزى مقطـع ب را در نرمافزار يلاكسيس و شكل V وضعيت تغييرات نشست با ارتفـاع 


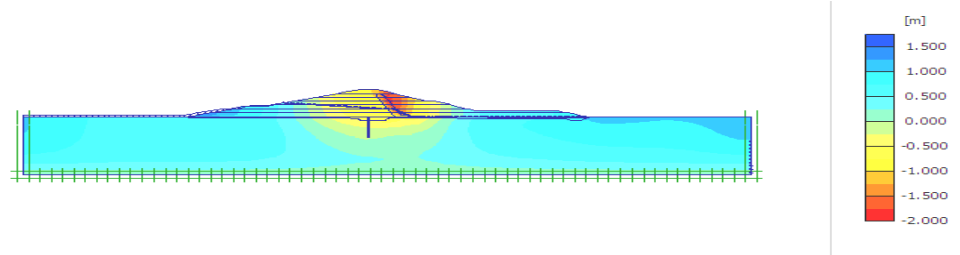

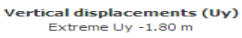

شكل 1 نشست در آخرين مرحله خاكريزى مقطع 19

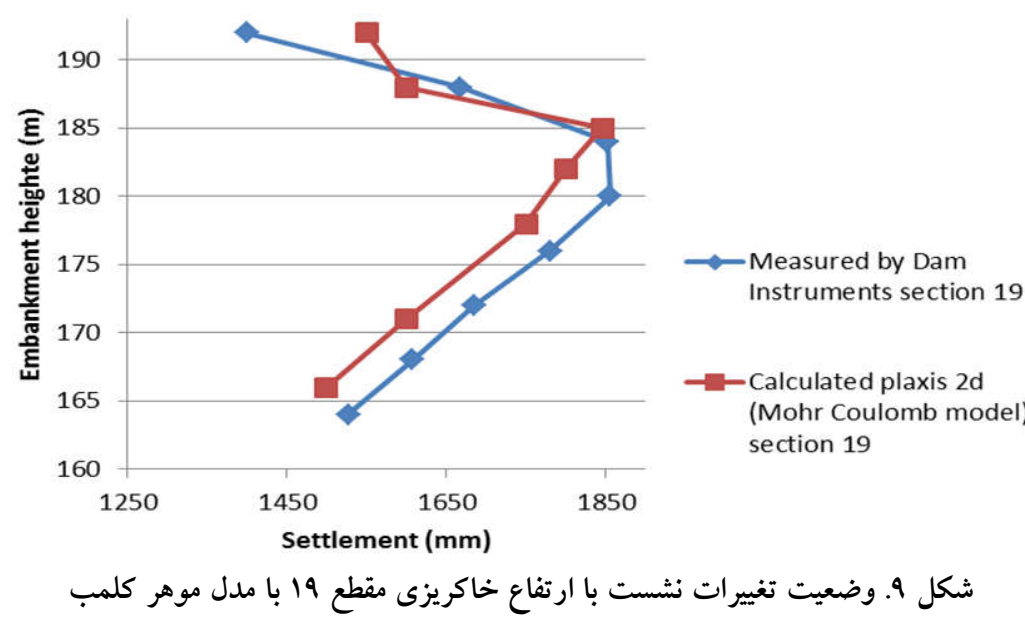

سختشونده جِون دادههاى بيشترى از خاى را دارا اسـت، رفتـار سد سدهاى خاكى را بهتر مى تواند مدلسازى كند. در ايـن مـدل اثر خزش يا نشست ثانويه كه معمولاً دردرازمدت اتفاق مسى افتـــ درنظر كرفته نمى شود. بديهى است با توجـهـ بـه اينكـه در طـول ساخت معمولاً نشست هاى اوليه اتفاق مى افتد، مدل سخت شونده كارايى بهترى مى تواند داشته باشد. در اين مدل نيز مقاومت برشى خاك بر اساس معيار موهر كولمب مشخص مىشود؛ اما ويزگى اصلى اين مدل درنظر گرفتن سختى وابسته به مسير و تنش وارده به توده خاى است. اين مدل داراى سختشوندگى همسان بـوده و مىتواند تغيير در اندازه سطح تسليم را درنظر كيرد. با توجه بــ تغييرات سختى بسته به مسير باركذارى و تـنش، اسـتفاده از ايسن مدل در يروزههايى كه باربردارى يا باركذارى بهميزان زياد انجـام مىشود، ماند ساخت خاكريزها مثل همين سد خـاكى كـه مــل شد توصيه مىشود. تفاوت مدل سختشونده با مدل موهر كلمب در بيشبينى نتايج ازمايش سه محورى است. شكل ه ا وضعيت تغييرات نشست با ارتفاع خـاكريزى مقطع 19 حاصـل از ابـزار
بدنه سد دارد. شكل ^ نشست در آخرين مرحله خاكريزى مقطع 19 را در نرمافزار يلاكسيس و شكل 9 وضعيت تغييرات نشسـت كيت

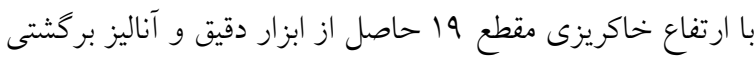
را نشان مىدهد. اندازه گيرى نشست معمولاً در سدهاى خاكى در بخش مركزى هسته رسى، با قرار دادن صفحات مغناطيسى در ترازهاى كوناكون

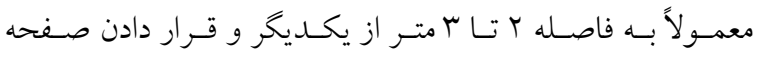
مغناطيسى مبنا در بايينترين تراز ممكن هسته رسى بهعنوان نقطـه مبنا و ثابت و سنجش نشست ساير نقاط نسبت به آن انـدازهيـرى مىشود. نشست سد را به دو بخش نشست در طول ساخت و بس بـ از ساخت و در دوران بهرهبردارى مى توان تقسيم كرد (1)).

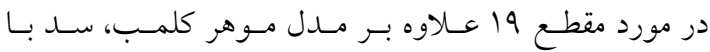
مدلهاى نرمشونده و سختشونده مدل شده است. همانطور كه در شكل ها و جدول ب كه مقايسه درصد خطـا بـين مـدلهــاى رفتارى خاى و ابزار دقيق سد را نشان مىدهد، مشاهده مىشـود مسـل سـختشـونده بــرازش بهتـرى را ايجــاد مسى كنـد. مـدل 
نشريه علوم آب و خاك (علوم و فنون كثاورزى و منابع طبيعى) / سال بيست و دو / شماره جهارم / زمستان IraV

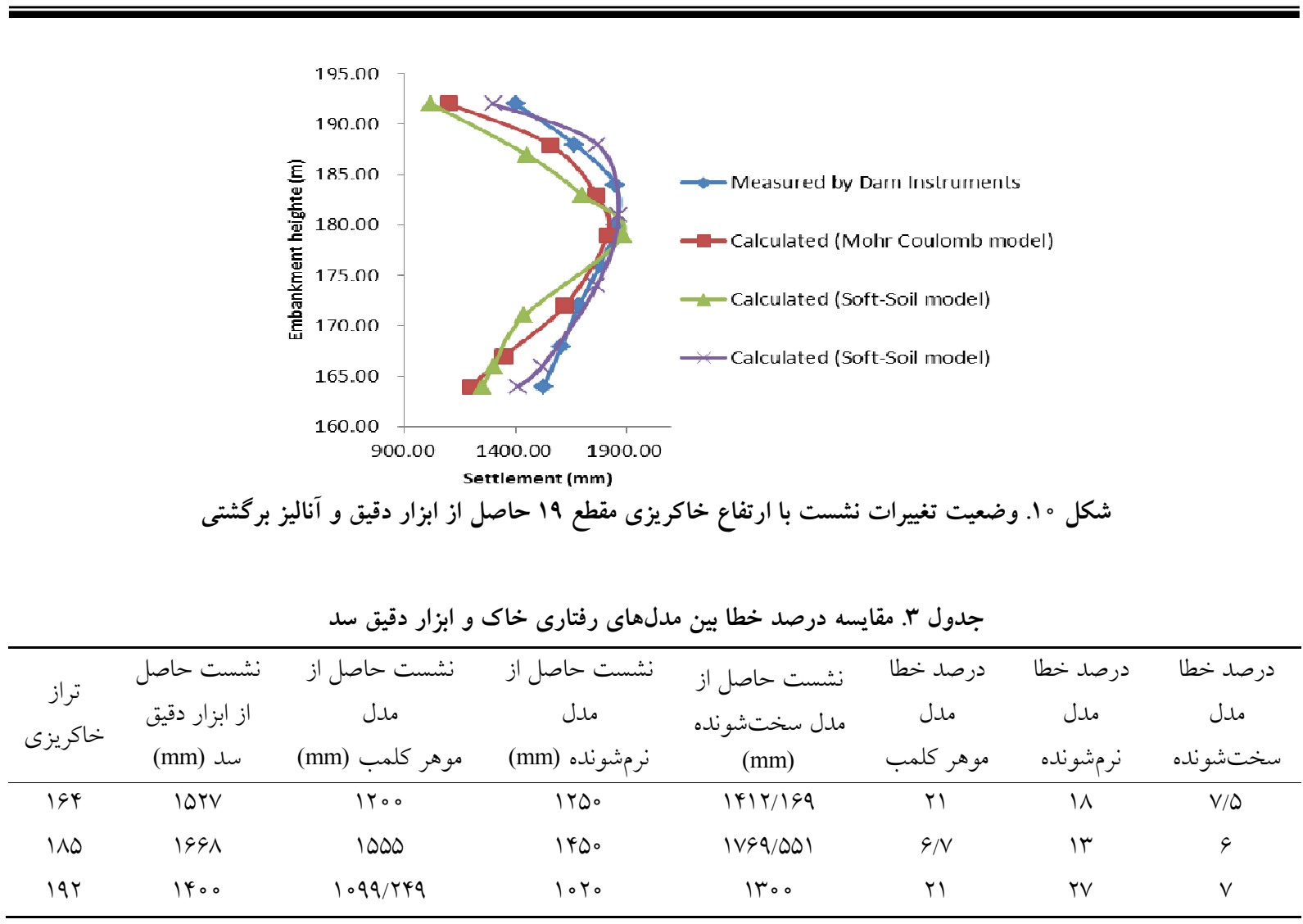

ساختخاه اين مهم قابل درك است. مقدار نشست تجمعى در يسى اين ساختخاه معادل ه م r ميلى متر است .

بر اساس دادهها، بيشترين نشست اختلافى در راستاى عرضى بدنه سد در اين مقطع از بخش ميانى رخ داده است. بهطورى كـه

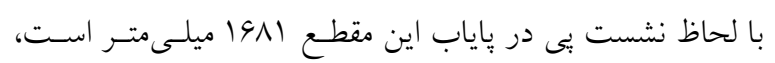
نشست اختلافى در راستاى عرضى مقطع به مقدار q49 ميلىمتـر محدود شده است [9]. شكل Iا نشست در آخرين مرحلـه خـاكريزى مقطع ها و و

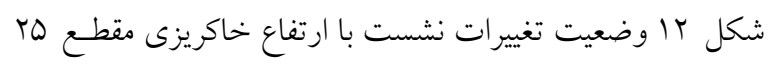

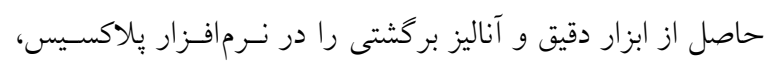

$$
\text { نشان مى نهد. }
$$

بررسى نشست مقطع rV مقطع ميانى ومقايسه مدل عـددى بــا

$$
\text { نتايج ابزار دقيق }
$$

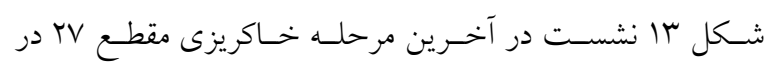

دقيق و آناليز بركشتى را نشان مى دهد. جدول r مقايسه درصد خطـا بين مدلهاى رفتارى خاى و ابزار دقيق سد را نشان مىدهد. در ايسن جدول، سه نقطه بهعنوان نمونه در بالاى مقطع و در تراز 194 و ميانـه

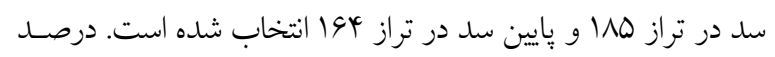

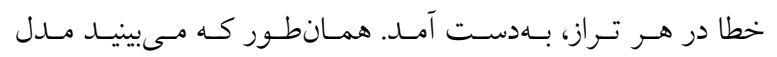
سختشونده در هر باتراز درصد خطايى كمترى دارد. بنابراين بـراى مدلسازى سدهاى خاى مدل سختشونده توصيه مىشود. بررسى نشست مقطع هO مقطع ميانى و مقايسه مدل عددى بـا نتايج ابزار دقيت

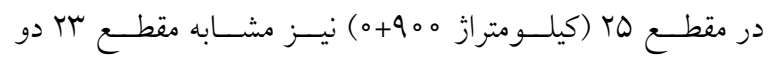
انحرافسنج به همراه صفحات نشست - سنجى نصب شدهاند. بـا توجه به شكل V، نشست بيشينه يیى سـد در ايسن مقطع رخ داده است كه با توجه به ضعيف بودن يسى ايسن بخـش از بدنـه سـد، سـرعت اجـراى خــاكريزى و قراركيـرى مقطع در خـط القعـر 


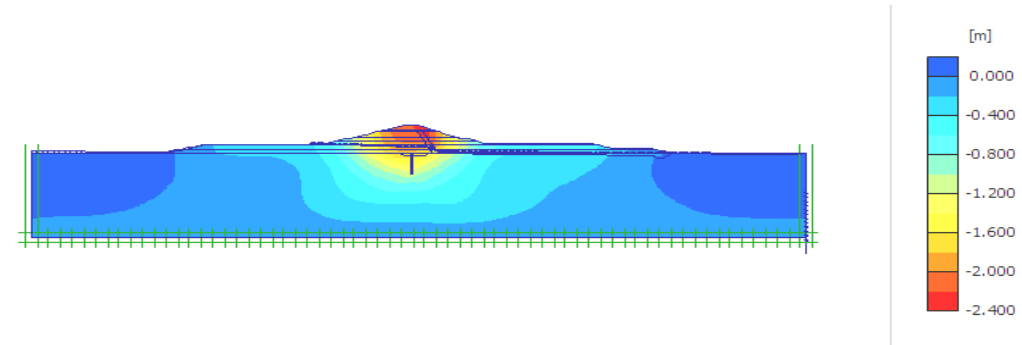

Vertical displacements (Uy)

Extreme Uy $-2.29 \mathrm{~m}$

Ho

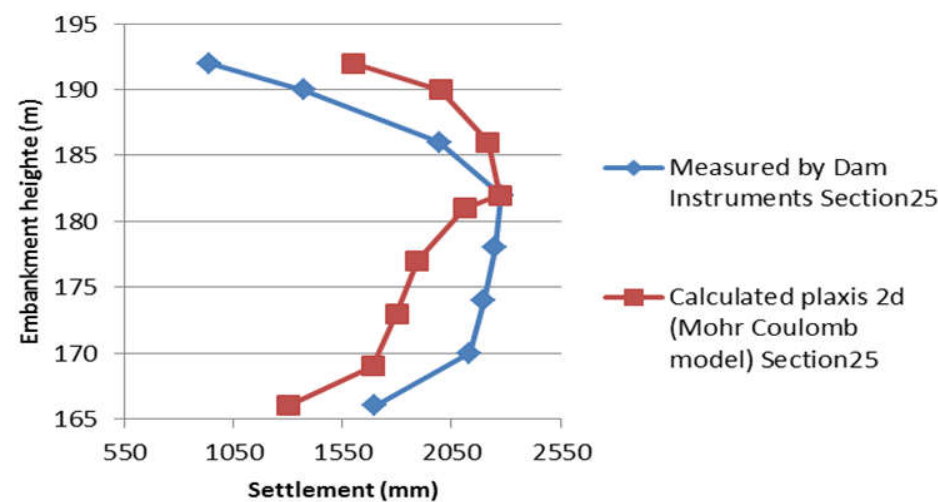

شكل r I. وضعيت تغييرات نشست با ارتفاع خاكريزى مقطع هr حاصل از ابزار دقيق و آناليز بركشتى
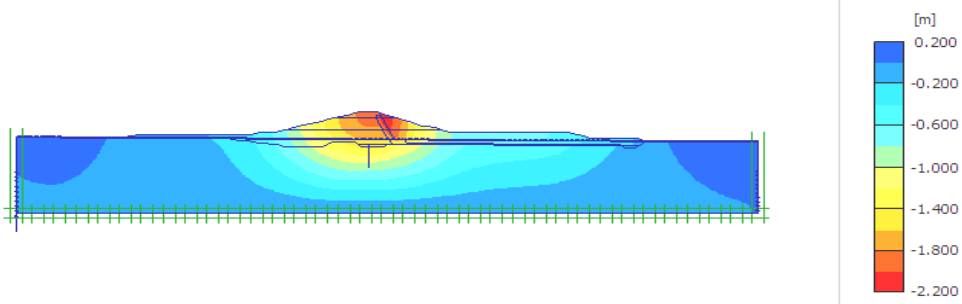

Vertical displacements (Uy)

Extreme Uy $-2.11 \mathrm{~m}$

MV TV Ir. نشست در آخرين مرحله خاكريزى مقطع

نرم|فزار بِلاكسيس را نشان مى دهد. وضعيت تغييرشكل هاى قـائم تغييرات نشست با ارتفاع خاكريزى مقطع بV حاصل از ابزار دقيق

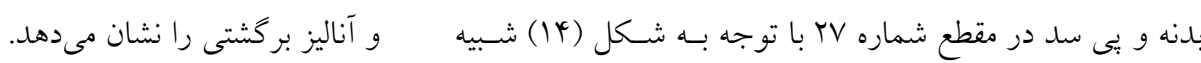

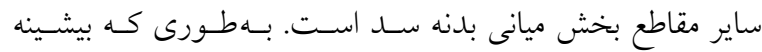

بررسى نشست مقطع هัr جناح راست سد ومقايسه مدل عددى

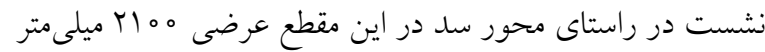

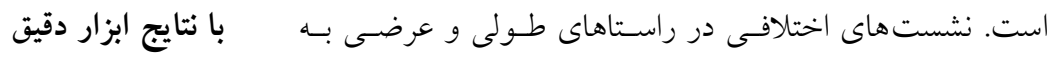

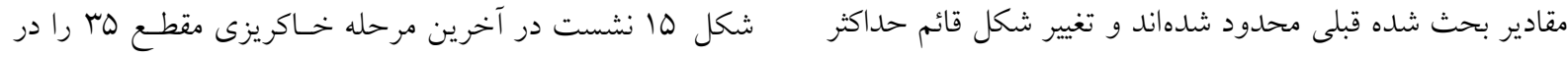

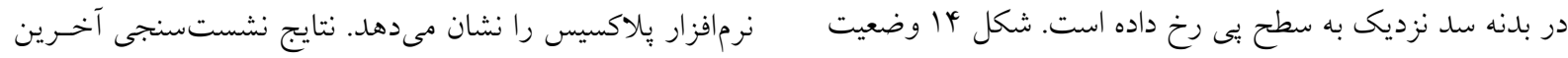


نشريه علوم آب و خاك (علوم و فنون كثاورزى و منابع طبيعى) / سال بيست و دو / شماره جهارم / زمستان ITVV

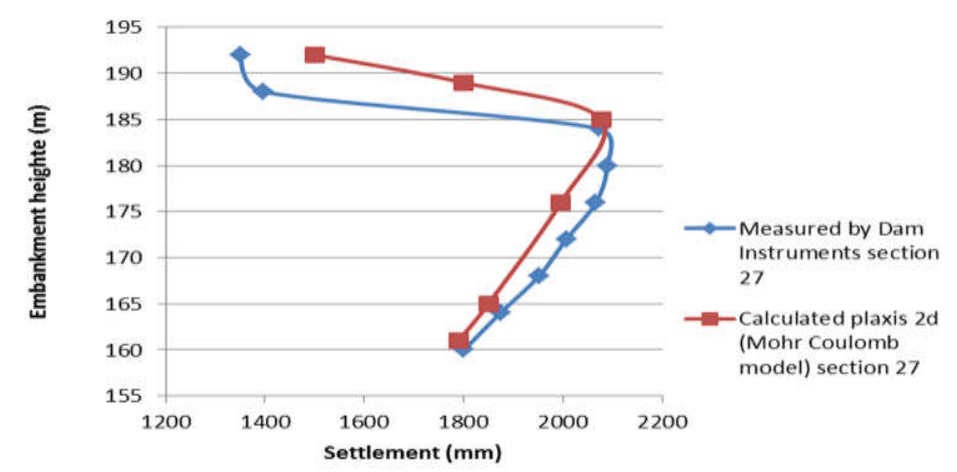

شكل \&F I. وضعيت تغييرات نشست با ارتفاع خاكريزى مقطع VV حاصل از ابزار دقيق و آناليز برگثتى
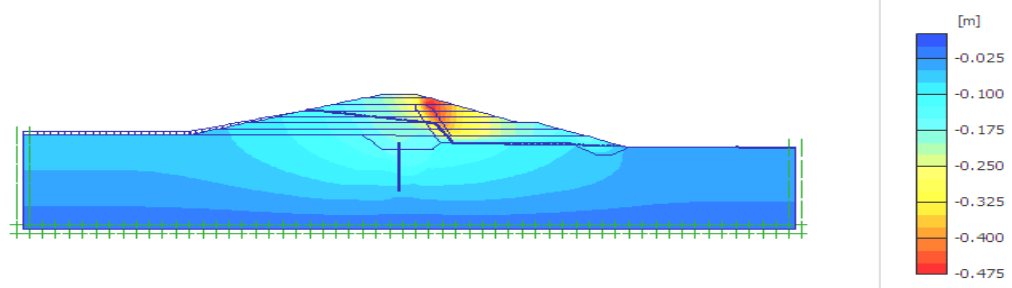

Vertical displacements (Uy)

Extreme Uy $-469.01^{*} 10^{-3} \mathrm{~m}$

شكل ها. نشست در آخرين مرحله خاكريزى مقطع هr

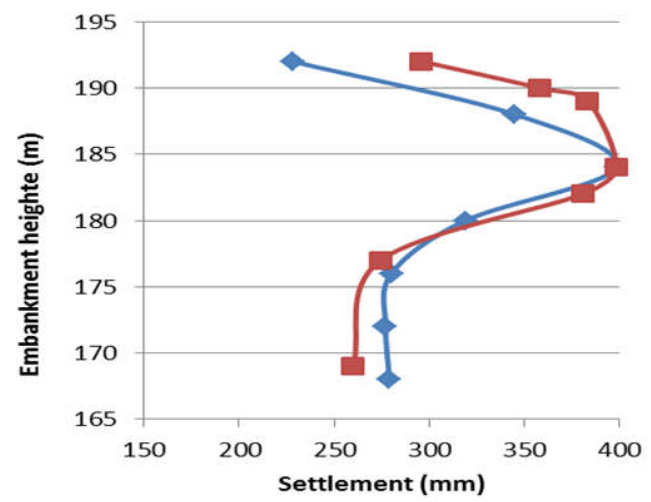

$\leadsto$ Measured by Dam

Instruments section 35

$\rightarrow$ Calculated plaxis $2 \mathrm{~d}$

(Mohr Coulomb model)

section 35

شكل 19. وضعيت تغييرات نشست با ارتفاع خاكريزى مقطع هr حاصل از ابزار دقيق و آناليز برگثتى

مقطع ابزارگذارى شده بدنه سد (مقطع هr) در شـكل 19 ارائـه آناليز برگشتى و را نشان مى دهد.

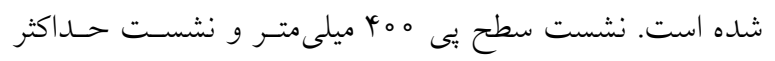
بدنه سا سـانتى متـر بـراى دوران قريـب بــه انتهـاى سـاخت و بررسى نشست مقاطع مختلف سد ومقايسه مدل عددى با نتايج بهترتيب وrq ميلى متر و IV/D سانتى متر يس از آبخيرى اوليـه و ابزار دقيق اتمام خاكريزى كامل بدنه سد است. شكل 19 وضعيت تغييرات در شكل IV نشست در هر مرحله خاكريزى را نشان مسىدهـد. نشست با ارتفاع خاكريزى مقطع هـ حاصـل از ابـزار دقيـق و بيشترين نشست در مرحله ينجم و كمترين نشسـت در مرحلـه 

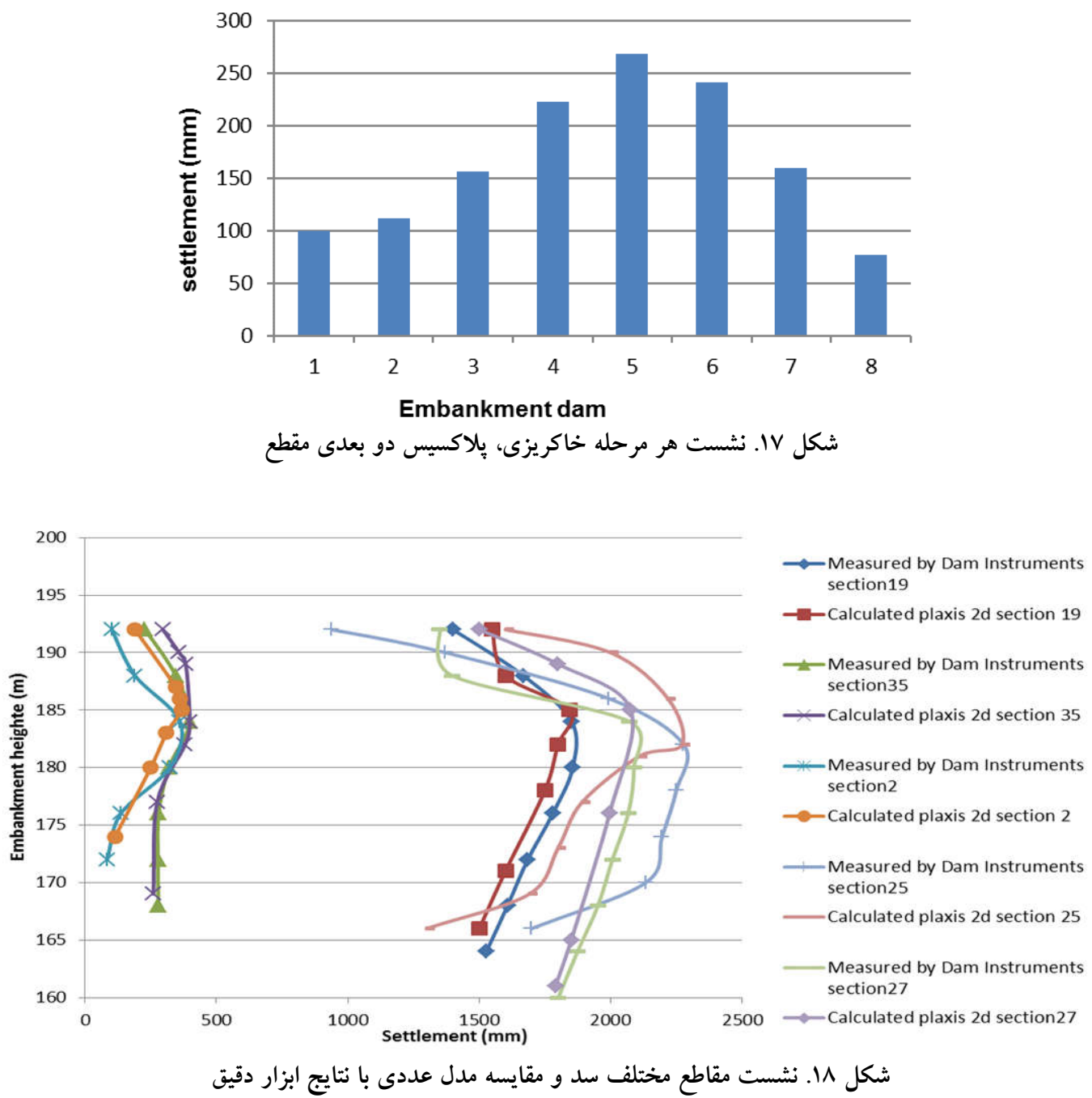

سد اتفاق مىافتد (IV ). نرمافـزار بِاكسـيس در ايسن مـدل هـم بيشترين مقدار نشست را تقريباً در قسمت ميانه سد نشان مىدهد كه اين مقايسه بهخاطر صحتسنجى نـرم|فـزار يلاكسـيس انجـام كرفته است. شكل \1 نشست هر مرحله خاكريزى، يلاكسيس دو بعدى مقطع 19 را نشان مىدهد. همانطور كه مىبينيـا بيشـترين

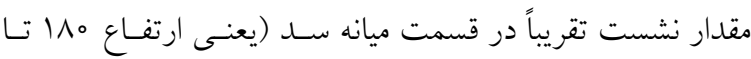

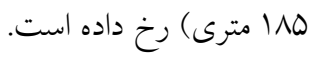
با توجه تحليل هاى انجام شده بــا نـــــــــار و دادههـاى ســـ نشست سد در موارد زير تحليل شده است.

حد فاصل مقاطع شماره V تا II بلنه سد جناح جֶٍ را تشكيل مىدهد. اين جناح محدوده حاد از نظر تغيير عمق سنخ بستر هست.
آخر رخ داده است. همانطور كه مى بينيـــ نشسـت تـا مراحـل ميانى روند افزايش را داشـته و ســس رونــــ آن كاهشسى بـوده است.شكل 11 مجموعه نتايج تفسير شده در فوق براى مقـاطع عرضى را در يكى تصوير نشان مىدهد. ارزيـابى ايسن نتـايج در كنار هم مؤيد اين مهم است كه تغيير شكل هاى قائم بدنه سد از سمت جناحين به سمت مقاطع ميانى افزايش يافتـه و بيشـترين نشست در مقطع Q D-TQ ثبت شده است. بنـابراين مسى تـوان از رفتار يكيارجه بدنه سد با لحاظ روند تغييرات نشستهـا را در

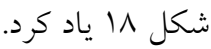
نشستهاى اندازهكيرى شده در بr ســ خـاكريزهاى بـزرى جهان نشان مىدهد كه بيشترين مقدار نشسـت در قسـمت ميانـه 
مناسبى با شرايط زئوتكنيكى :هى، نحسوه باركـذارى بدنـه، زمـان

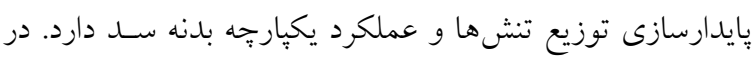

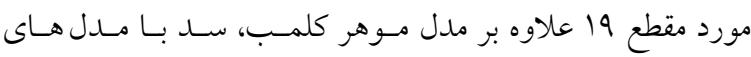

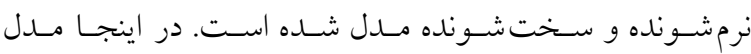

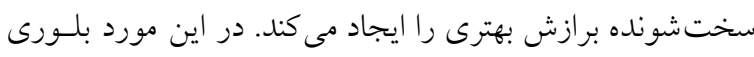

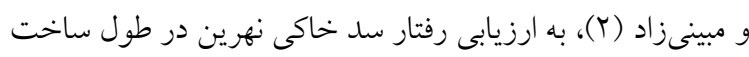

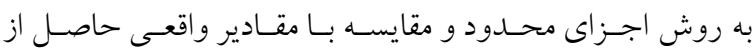

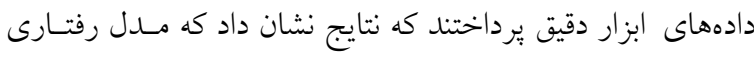
سختشونده برازش بهترى در مورد سد نهرين داشت و كه ايسن

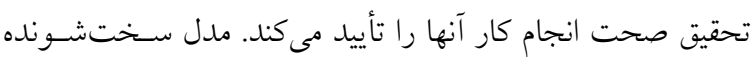

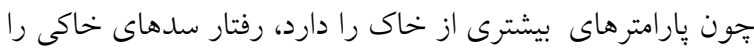

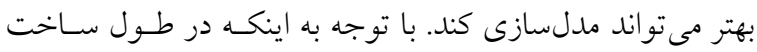

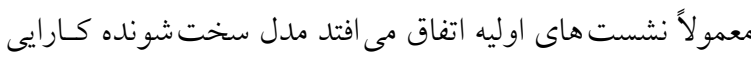
بهترى مى تواند داشته باشد. با توجه به تغييرات سـختى بسـته بـه

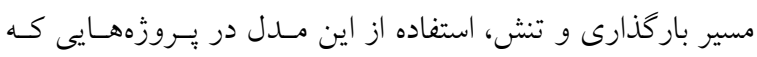

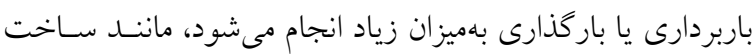
خاكريزها مثل همين سد خاكى كه مدل شد، توصيه مى شـود. در

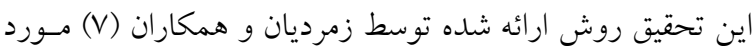

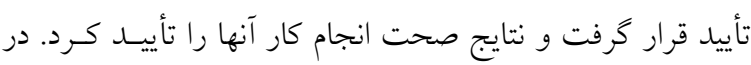

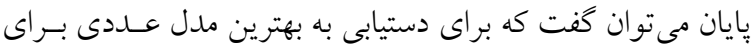

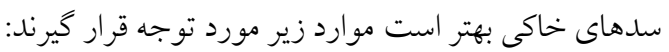

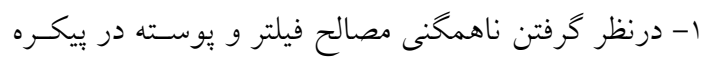

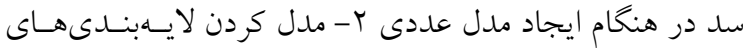

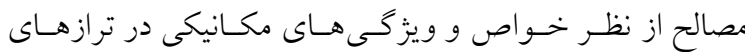

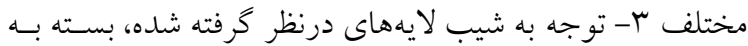

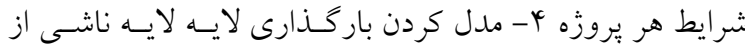
احداث سد در هنخام ساخت مدل عددى ه- استفاده از يلكـان زمانى 9- استفاده از مدل رفتارى خاك سختشــونده بـهـ جـاى مدلهاى رفتارى خطى يا نرمشونده و يـا تركيـب آنها بـا مــدل

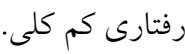

وضعيت يى و مصالح تشكيل دهنده آن در جناح راست سد،

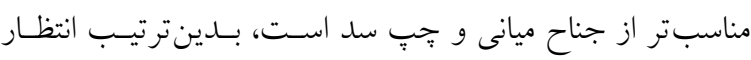

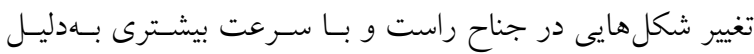
درشت دانهتر شدن بي قابل انتظار است.

\section{نتيجه گيرى}

در بحث هاى فوق، تغييـرات نشسـت در عمـق بدنـه و يـى ســـ

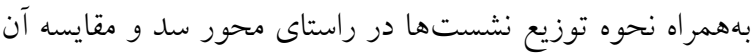

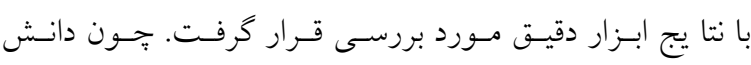

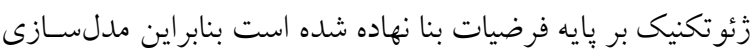

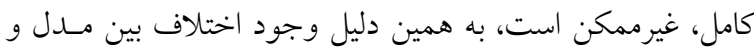

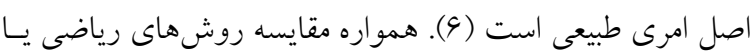

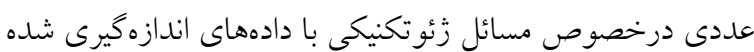
دقت اين روشها در يك يروزه خــاص، تعيسين مسى كنـد. در ايسـن

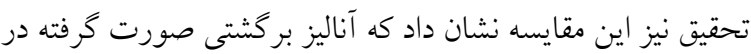

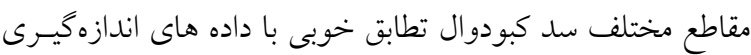

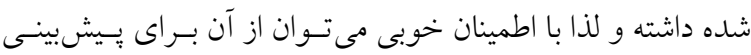

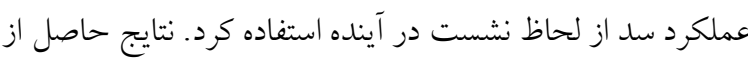

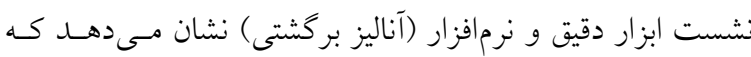

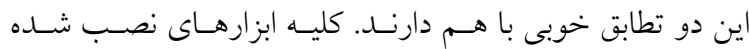

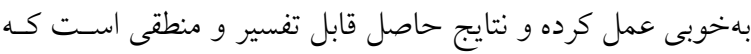
نشان دهنده دقت نصب و قرائت است. ارزيابى اين نتايج در كنار

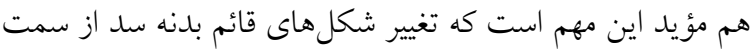

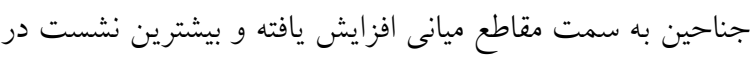

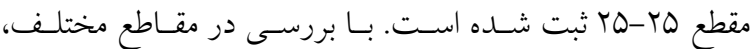

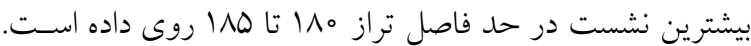
يعنى تراز خاكريزى در ايـن اعــاد بحر انسى بـوده اسـت. عمـــه

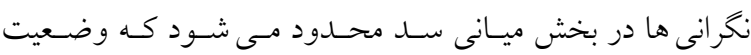

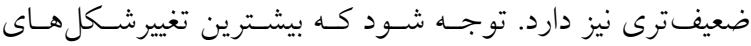

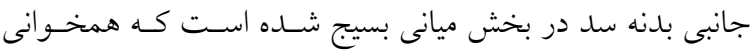




$$
\begin{aligned}
& \text { منابع مورد استفاده }
\end{aligned}
$$

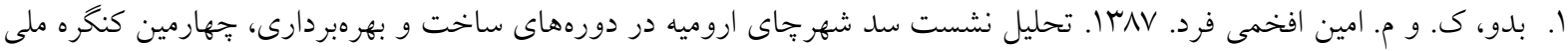

$$
\begin{aligned}
& \text { مهندسى عمران، تهران. }
\end{aligned}
$$

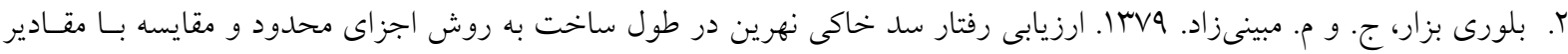

$$
\begin{aligned}
& \text { واقعى. مجله يُزوهش آب /يران ب( (9): }
\end{aligned}
$$

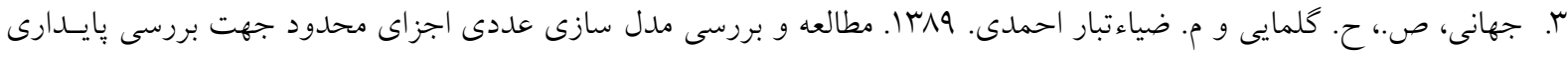

$$
\begin{aligned}
& \text { شيروانى ها در حين ساخت و يرشدن و افت سريع مخزن (مطالعه موردى سد ميجران با استفاده از نـرم افـزار Plaxis). يايـان نامـه } \\
& \text { كارشناسى ارشد، دانشخاه علوم كشاورزى و منابع طبيعى سارى. }
\end{aligned}
$$

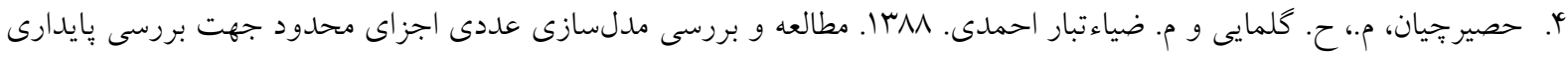

$$
\begin{aligned}
& \text { شيروانىها درحين ساخت و يرشدن و افت سريع مخزن. نهمين كنخره بين المللى مهندسى عمران، دانشخاه صنعتى اصفهان }
\end{aligned}
$$

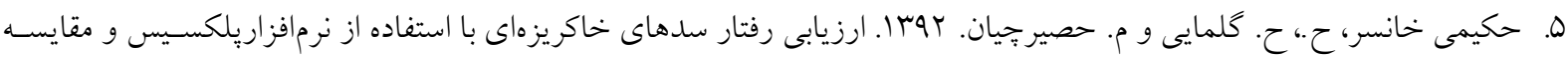

$$
\begin{aligned}
& \text { آن با نتايج ابزار دقيق (مطالعه موردى سد كبودوال). ياياننامه كارشناسى ارشد وهץ ا، دانشخاه علوم كشاورزى و منابع طبيعى سارى. }
\end{aligned}
$$

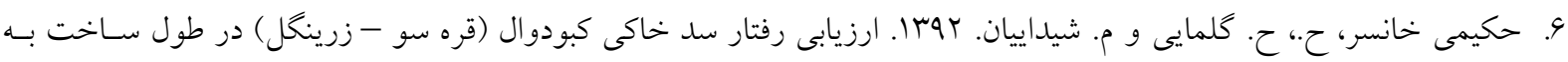

$$
\begin{aligned}
& \text { روش اجزاى محدود با نرمافزار PLAXIS و مقايسه با مقادير واقعى حاصل از داده هاى ابزار دقيـق. مجلسه علـوم و مهندسسى آب }
\end{aligned}
$$

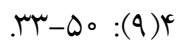

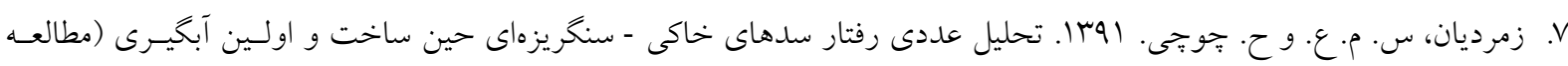

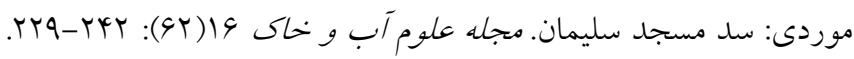

$$
\begin{aligned}
& \text { ^. شركت سهامى آب منطقهاى كلستان. الوبا. دادههاى ابزار دقيق سد كبودوال سال. كلستان. } \\
& \text { 9. شركت سهامى آب منطقهاى گلستان. rوبا.گزارش رفتارسنجى سد كبودوال سال. كلستان. } \\
& \text { ه ا. شركت مادر تخصصى آزمايشگاه فنى و مكانيك خاك استان كلستان. rوبا. گزارشات مصالح قرضه آزمايشخاهى تحليل هاى بدنه } \\
& \text { فنى و ابزاردقيق سد كبودوال. كلستان. }
\end{aligned}
$$

11. ASCE Task Committee. 2000. Guidelines for Instrumentation and Measurements for Monitoring Dam Performance. ASCE. USA

12. Chen X, Shiwei B.2003. Research on creep-consolidation characteristics and calculating model of soft soil. Chinese Journal of Rock Mechanics and Engineering 22(5): 728-734. (In Chinese).

13. Duncan, J. M. and C. Y. Chang. 1970. Nonlinear analysis of stress and strain. ASCE Journal of Soil Mechanics and Foundation Division 96:1629-1653

14. Dunnicliff, J. 1993. Geotechnical Instrumentation for Monitoring Field Performance. John Wiley and Sons Inc. USA.

15. Indraratna, B., A. S. Balasubramaniam and P. Ratnayake. Performance of embankment stabilized with vertical drains on soft clay. Journal of Geotechnical Engineering 120(2): 257.

16. Mir-Mohammad-Hosseiny S. M. and R. Ahmadi-Fard. 2003. Pore pressure development in the core of earth dams during simultaneous construction and impounding. Electronic Journal of Geotechnical Engineering 8: Bundle A.

17. Myers, B. and J. Statelier. 2008. Why Include Instrumentation in Dam Monitoring Programs? United States Society on Dams. Committee on Monitoring of Dams and their Foundations. United States.

18. Pagano L., A. Desidri and F. Vinale. 1998. Interpreting settlement profiles of earth dams. Journal of Geotechnical and Geo environmental Division. ASCE 124(10): 923-932

19. Plaxis 2D, General Information- Reference and Scientific Manual. 2001. Version 1. A. A. Balkema Brinkgreve R.B.J. and Vermeer P.A.

20. US Army Corps of Engineers. 1995. Instrumentation of Embankment Dams and Levees Engineering and Design. 
Washington DC.TMax A. M. Herzog Practical Dam Analysis.Consulting Engineer.

21. Weibing, Z., C. Yonghu and G. Youpin.1998, A methodology for modeling sand-drain ground in plain strain analysis. Journal of Hydraulic Engineering 43(6): 53-57. (In Chinese).

22.Zhiwan Y., Z. Weibing and G. Ji. 2003. 3-D FEM Analysis of Soft Viscoelastic/Viscoplastic Foundation with Drainage Preloading. Journal of Hohai University 23(5): 1-7. (In Chinese).

23.Zongze, Y. 1988. One double yield surface constitutive model of soil. Chinese Journal of Geotechnical Engineering 10(1): 64-71. (In Chinese). 


\title{
Investigation of the Structure of the Dam Body during Construction and its Comparison with the Analytical Results Using PLAXIS Software (the Case Study of Kaboodvall Dam)
}

\author{
F. Salmasi, H. Hakimi Khansar* and B. Norani ${ }^{1}$
}

(Received: July 11-2017 ; Accepted: January 15-2018)

\begin{abstract}
Modeling of Kaboodval Dam using Plaxis software has been used for the Mouher-Columb behavior model. The effect of two continuities of embankment and watering operations on the meeting was considered. The body structure of the dam was increased from the side of the faces to the middle sections, and the maximum seating was recorded at 25-25 and at about $2200 \mathrm{~mm}$. By examining at different intervals, the largest meeting was in the range of 180 to 185 . That is, the level of the embankment was found to be critical in these numbers. Most concerns were regarding the middle of the dam, which had a weaker position. According to the analysis of different parts of Kaboudvall Dam, the materials forming the right wing of the dam in the middle and left wings of the dam were better. In the case of the 19th Module, besides the Mouher-Columb model, the dam could be modeled with hardening and hardening models. Here, the hardening model created a better fit. The hardening model, as it could get more data from the soil, is likely to better model the behavior of the soil dams. Due to the fact that, during the construction, the first sessions usually occur, the hardening model can have a better performance.
\end{abstract}

Keywords: Dam, Dam Kaboodval, Plaxis, Soil subsidence

1. Department of Water Engineering, Faculty of Agriculture, Tabriz University, Tabriz, Iran.

*: Corresponding Author, Email: hakimi1904@yahoo.com 